\title{
JENIS DAN MOTIF KONSTRUKSI APOSISI DALAM BAHASA JAWA
}

\section{TYPES AND MOTIVES OF OPPOSITION CONSTRUCTION IN JAVANESE LANGUAGE}

\author{
Titis Bayu Widagdo, Sumarlam \\ Universitas Negeri Sebelas Maret Surakarta \\ Ponsel: 08520426630; Pos-el: bayutitis9@gmail.com, sumarlamwd@gmail.com
}

Naskah Diterima: 22 Juli 2019; Direvisi: 4 Desember 2019; Disetujui: 4 Desember 2019

DOI https://doi.org/10.26499/mab.v13i2.249

\begin{abstract}
Abstrak
Penelitian ini bertujuan untuk memaparkan jenis kontruksi aposisi dalam bahasa Jawa serta mengungkap motif penggunaan aposisi dalam media massa berbahasa Jawa. Media cetak yang menjadi sumber data adalah Panjebar Semangat edisi Februari-Mei 2019, dalam rubrik Pangudarasa. Data berupa kalimat, kemudian dianalisis dengan teknik permutasi dan ellipsis sehingga penulis dapat memaparkan jenis konstruksi aposisi yang terdapat dalam bahasa Jawa motif tujuan penggunaan aposisinya. Hasil penelitian menjelaskan bahwa dalam majalah Panjebar Semangat terdapat tiga pola aposisi yang digunakan, yaitu aposisi penuh, aposisi sebagian atau aposisi mewatasi, dan aposisi tak mewatasi. Merujuk pada motifnya, dalam majalah Panjebar Semangat ditemukan 8 motif aposisi, yaitu ketercukupan informasi, kejelasan istilah, pemberian informasi baru, kompetisi bahasa, pembentukan citra tokoh, instansi atau lembaga, penekanan emosi, penghormatan, dan pembangun humanisme.
\end{abstract}

Kata-kata kunci: Panjebar Semangat; aposisi; konstruksi aposisi; motif aposisi

\begin{abstract}
This study aims to describe the types of construction of the apposition in Javanese language and to reveal the motives for using the apposition in Javanese mass media. The target mass media was the February-May 2019 edition of Panjebar Semangat, in the Pangudarasa rubrik. Data in the form of sentences, then analyzed by permutation techniques and ellipsis so that it can describe the type of construction of the existing apposition in the Java language to be the motive for the purpose of using the aposition. The results of the study explain in Panjebar spirit magazine there are four patterns of appitions used, namely full apposition, partial apposition or non rescrictive apposition, and rescrictive apposition. Referring to his motive, in the Panjebar Semangat magazine there were found 8 motives of apposition, namely the adequacy of information, clarity of use, the provision of new information, language competition, the excavation of the image of leaders, institutions and institutions, transition, government, respect and builders of humanism.
\end{abstract}

Keywords: Panjebar Semangat; aposition; aposition construction; aposisi motive 


\section{Pendahuluan}

Informasi merupakan sebuah pesan atau pemberitahuan untuk memenuhi kebutuhan manusia dalam berinteraksi di kehidupan sehari-hari. Pesan tersebut akan tersampaikan kepada penerima dengan baik, jika pengirim menggunakan penjelasan yang akurat. Agar informasi tersampaikan secara jelas dan akurat, salah satu unsur kebahasaan yang dapat dimanfaatkan adalah aposisi. Aposisi tidak hanya berfungsi sebagai alat komunikasi tetapi juga dapat menjadi unsur kebahasaan yang mempermudah ketersampaian informasi secara rinci.

Aposisi merupakan perluasan dari kalimat tunggal dengan cara menambahkan unsur kalimat (biasanya unsur nominal). Curme (1947:129) memaparkan bahwa aposisi adalah satuan lingual berkategori benda yang berfungsi menjelaskan atau mencirikan satuan lingual lain dan menempati tempat di samping kontruksi pertama.

Merujuk pada konsep di atas, peneliti ingin mengungkap bagaimana kontruksi dan motif dari penggunaan aposisi yang ada dalam bahasa Jawa. Hal tersebut dilakukan karena aposisi dalam bahasa Jawa merupakan objek yang jarang diteliti dan dikesampingkan, padahal, dalam penggunaannya aposisi memiliki peran penting dalam membangun informasi yang lengkap dan utuh pada suatu kalimat.

Penelitian ini berfokus pada motif aposisi bahasa Jawa dalam ranah jurnalistik. Peneliti menentukan fokus pada penggunaan aposisi bahasa Jawa pada majalah Panjebar Semangat disingkat PS. Majalah ini dipilih karena majalah PS merupakan majalah berbahasa Jawa yang masih tetap eksis sampai saat ini. Selain itu, dalam penyampaian informasi atau berita, majalah PS terkenal dengan pola berbahasa yang lebih sederhana dan menarik daripada majalah berbahasa Jawa yang lain. Dari pola yang sederhana dan menarik tersebut, peneliti mencoba menganalis aspek aposisi dalam salah satu rubriknya. Dalam penelitian ini, peneliti memilih rubrik Pangudarasa.

Rubrik Pangudarasa dipilih dalam penelitian ini didasari oleh beberapa faktor, antara lain informasi atau berita yang ditulis dalam rubrik ini merupakan informasi yang sedang hangat diperbincangan. Selanjutnya, secara konsep rubrik Pangudarasa dalam penyampaian informasinya memberikan ruang pembaca untuk berinterpretasi secara bebas sehingga penggunaan aposisi sangat penting dalam rubrik ini untuk menghindari kesalahan interpretasi 
karena keambiguitasan informasi. Berdasarkan faktor tersebut peneliti memfokuskan kajian pada jenis dan motif aposisi dalam rubrik Pangudarasa edisi Februari-Mei 2019.

Untuk mempertajam penelitian ini, peneliti melakukan studi pustaka dengan menjadikan penelitian-penelitian terdahulu sebagai acuan atau dasar penelitian ini. Tulisan terkait aposisi yang pertama sebagai acuan peneliti adalah tulisan Alwi dkk., (2010). Alwi, dkk., dalam Tata Bahasa Baku Bahasa Indonesia menjelaskan jenis atau tipe aposisi. Alwi dkk., membagi jenis-jenis aposisi menjadi tiga jenis, yaitu aposisi penuh, aposisi sebagian (aposisi tak mewatasi), dan aposisi mewatasi.

Ardhian (2013) menjelaskan motif penggunaan aposisi. Penelitian tersebut mengungkapkan tujuh motif aposisi, yaitu memberikan informasi baru, membangun keefektifan kalimat secara utuh, membentuk citra tokoh, kompetisi bahasa, penjelas istilah, membangun sisi humanis, dan menghadirkan informasi yang cukup.

Cahyana (2017) menjelaskan bahwa aposisi pada teks berita utama Jawa Pos. Dalam penelitiannya ditemukan jenis aposisi yang digunakan, yaitu aposisi pembatas (aposisi yang mewatasi pronominal). Kemudian, dari motif tujuan penggunaan aposisi, ditemukan terdapat empat motif, yaitu edukasi kepada masyarakat, membangun citra, kompetisi bahasa, dan ketercukupan informasi.

Berdasarkan studi pustaka yang telah dipaparkan sebelumnya, penelitian aposisi bahasa Jawa dalam Majalah PS khusunya pada rubrik Pangudarasa penting dilakukan, karena penelitian terdahulu terkait aposisi bahasa daerah masih sangat jarang ditemukan. Untuk itu penelitian ini mencoba menghadirkan khasanah pengetahuan baru dalam kajian aposisi bahasa Jawa. Selain itu, penelitian ini juga akan memapaparkan motif-motif baru dan berbeda dari penggunaan aposisi sebagai pelengkap informasi.

\section{Landasan Teori}

\subsection{Aposisi dan jenis Aposisi}

Matthews, (1997:22) menjelaskan bahwa oposisi merupakan hubungan elemen-elemen yang berdekatan dan tidak memiliki perbedaan referen. Selaras dengan pendapat di atas, Alwi, dkk., (2010:385) menyatakan dua unsur kalimat dapat disebut beraposisi jika kedua unsur itu sederajat dan mempunyai acuan yang sama atau paling tidak, salah satu mencakupi unsur lainya pada kalimat. 
Favre dan Dilek (2009:2771) juga menyatakan bahwa aposisi merupakan konstruksi gramatikal yang melibatkan dua frasa benda yang saling bertalian, salah satunya mendefinisikan atau memodifikasi yang lain.

Aposisi dalam konstruksi kalimat tidak memiliki posisi yang pasti. Paladian (2003) dan Ardhian (2013:2) menjelaskan bahwa posisi aposisi tidak dapat ditetapkan dengan pasti apakah di depan ataukah di belakang nomina. Kenyataanya, peran semantiklah yang memutuskan posisi dan konsekuensinya tentang posisi aposisi.

Tujuan dari penggunaan aposisi dalam suatu kontruksi kalimat adalah sebagai penjelas atau penambah informasi dari nomina yang biasanya berkategori subjek. Menurut Sugono (2009:91) keterangan aposisi merupakan pemberi penjelas nomina, misalnya subjek. Keterangan aposisi dapat menggantikan unsur yang diterangkan.

Dari pemaparan tersebut, dapat ditarik benang merah bahwa aposisi merupakan unsur kalimat sederajat yang memiliki acuan yang sama dan berada dalam kategori yang sama serta dapat perposisi di depan atau belakang unsur nominanya yang bertujuan sebagai penjelas atau penambah informasi nomina.

$$
\text { Alwi, dkk., (2010:385--387) }
$$

menjelaskan jenis-jenis aposisi antara lain aposisi penuh, aposisi sebagian atau aposisi tak mewatasi, dan aposisi mewatasi. Aposisi penuh memiliki pengertian jenis aposisi yang dapat saling menggantikan. Aposisi sebagian (aposisi tak mewatasi) adalah aposisi yang tak dapat saling menggantikan. Terakhir, aposisi mewatasi adalah aposisi yang mewatasi nomina.

\subsection{Majalah Jayabaya}

Majalah PS adalah majalah mingguan berbahasa Jawa yang terbit di Surabaya. Majalah ini pertama kali terbit pada 2 September 1993. Panjebar Semangat didirikan oleh Dr. Soetomo. Majalah tersebut masih populer di kalangan masyarakat terutama di pulau Jawa yang sebagian penduduknya masih menggunakan bahasa Jawa sebagai alat komunikasi dan juga menjadi bahasa ibu. Bahasa Jawa yang digunakan dalam PS memiliki ciri khas yaitu mudah dipahami dan pilihan diksinya pun diksi sehari-hari.

Rubrik yang menjadi fokus penelitian ini adalah Rubrik Pangudarasa atau dalam bahasa Indonesia diartikan 'melatih pikiran'. Rubrik Pangudarasa ini menampilkan berita-berita yang hangat 
dan sedang diperbincangkan. Kemudian dikemas sedemikian rupa untuk menghadirkan daya berpikir kritis para pembaca dalam menanggapi berita tersebut. Jadi, peran aposisi yang kental dalam membangun informasi berita tersebut.

\section{Metode Penelitian}

Penelitian ini menggunakan metode kualitatif. Metode kualitatif digunakan dalam penelitian ini guna memaparkan secara holistic fenomena penggunaan aposisi berserta motifnya dalam penggunaanya di media masa berbahasa Jawa khusunya pada majalah PS.

Teknik pengumpulan data pada penelitian ini adalah teknik simak dan teknik catat. Menurut Sudaryanto (2015:203), metode simak atau penyimakan dilakukan dengan menyimak, yaitu menyimak penggunaan bahasa. Kemudian data yang sesuai akan dicatat.

Pada teknik analisis data, peneliti menerapkan metode agih, dan teknik lesap, serta teknik balik untuk menguji keapositifan suatu kalimat. Metode agih menurut Sudaryanto (2015:18) adalah metode yang memanfaatkan bagian dari bahasa itu sendiri sebagai alat penentu. Setelah itu, peneliti menginterpretasi data berkaitan dengan kontruksi dan motif atau tujuan penggunaan aposisi bahasa Jawa dalam praktik jurnalistik khusunya pada majalah PS.

\section{Pembahasan}

Dalam hasil dan pembahasan ini, akan dibagi menjadi dua subbagian, yaitu jenis-jenis aposisi dan motif penggunaan aposisi dalam bahasa Jawa.

\subsection{Jenis-jenis aposisi dalam bahasa}

\section{Jawa}

Berdasar data penelitian ini, ada tiga jenis aposisi, yaitu aposisi penuh, aposisi sebagian atau tak mewatasi, dan aposisi mewatasi. Berikut pemaparannya.

\section{a) Aposisi Penuh}

Menurut Alwi, dkk., (2010: 385), aposisi penuh adalah aposisi yang dapat saling menggantikan. Aposisi tersebut ditemukan dalam majalah PS sebagai berikut.

(1) Senajan wis kaping papat ngumumake kamenangan ing pemilu 2019, kubu Capres Cawapres no 2, Prabowo Subianto-Sandiaga Uno isih nuding pemilu kebak kecurangan lan ngusulake pembentukan tim pencari fakta. (PS 19/11-5-19)

'walaupun sudah empat kali mengumumkan kemenangan dalam pemilu 2019, kubu Capres-Cawapres no 2, Prabowo Subianto-Sandiaga Uno masih menuding pemilu penuh dengan kecurangan dan mengusulkan pembentukan tim pencari fakta'.

(2) Wakil Ketua MPR Hidayat Nurwahid ngempuli (adhine kendhang - Red), Jokowi mung mbacutake dalan-dalan 
gaweyane Bung Karno. (PS 9/24-219)

'Wakil Ketua MPR Hidayat Nurwahid menambahkan, Jokowi hanya meneruskan jalan-jalan yang dibuat Bung Karno'.

(3) Saka kene iki bakal bisa ndayani lan mrabawani calon pemilih, utamane wong-wong sing asikep golongan putih (Golput). (PS 12/ 2-3-19)

'Dari sini akan bisa menguatkan dan memberanikan calon pemilih, atau orang-orang yang bersikap golongan putih (Golput)'.

Perluasan nomina pada data nomor (1)--(3) memiliki karakteristik dapat saling menggantikan satu sama lain maka data tersebut disebut kontruksi aposisi penuh. Data (1) dan (2) perluasan nomina pada kategori subjek. Capres-Cawapres Prabowo Subianto-Sandiaga uno dan Wakil ketua MPR Hidayat Nurwahit masing-masing merupakan frasa nominal. Data (1) aposisi penuh yang mengacu pada informasi nama capres dan cawapres, sedangkan data (2) mengacu pada nama pemangku jabatan. Kedua pola kontruksi di atas disebut aposisi penuh karena dapat saling menggantikan dalam kontruksi kalimat tanpa mengubah makna.

Data (3) memiliki perbedaan dari segi posisi aposisi. Aposisi yang biasa ditemukan dalam kategori subjek, tetapi pada data di atas aposisi berposisi dikategori objek. Aposisi di atas merujuk pada penyingkatan istilah, yaitu golongan putih atau Golput. Data tersebut dikategorikan aposisi penuh karena dalam kontruksi kalimat dapat saling menggantikan.

\section{b) Aposisi Sebagian atau Tak Mewatasi}

Aposisi sebagian merupakan aposisi yang hanya salah satu konstituennya yang dapat menggantikan dalam kontruksi kalimat. Berikut data yang menunjukkan konstruksi aposisi sebagian atau tak mewatasi.

(4) Mangka Capres alternatif mau sedinane mung tukang pijet refleksi saka Desa Golantepus Kec. Mejobo sing bukak kios ing Pasar Brayung, Kudus (Jateng). (PS 13/ 25-3-19)

'Padahal Capres alternatifnya itu hanya tukang refleksi dari Desa Golontepus Kec. Mejobo yang membuka kios di Pasar Brayung, Kudus (Jateng)'.

(5) Korupsi dadi masalahe rakyat, jer kadurjanan iki mitunani sakabehing warga, najan ora langsung krasa lan dirasakake. (PS17/ 27-4-19)

'Korupsi menjadi masalah bagi rakyat, itu adalah kejahatan bagi semua warga, walaupun tidak langsung terasa dan dirasakan'.

(6) Indonesia, negara pengekspor TKI sing gedhe, senajan singgedhe... (PS14/6-4-19)

'Indonesia, negara pengekspor TKI yang besar, walaupun terbesar ....'.

Pada contoh-contoh aposisi di atas, konstituen kedua tidak dapat menggantikan konstituen pertama, 
contohnya data (6) kontituen kedua yaitu negara pengekspor TKI sing gedhe 'negara pengekspor TKI yang besar' tidak dapat menggantikan kontituen pertama, yaitu Indonesia. Jika dipaksakan untuk menggantikan maka konstruksi kalimat tersebut tidak gramatikal atau tidak dapat memberikan informasi secara utuh.

Selanjutnya, pada data (4)--(5) tampak bahwa konstituen-konstituenya dipisahkan dengan tanda koma. Hal tersebut mengisyaratkan konstituen kedua tidak mewatasi konstituen pertama. Atas dasar hal tersebut kontruksi pada contoh di atas disebut konstruksi aposisi sebagian atau aposisi tak mewatasi.

\section{c) Aposisi Mewatasi}

Aposisi mewatasi adalah aposisi yang salah satu konstituennya membatasi kontituen lain dalam kontruksi kalimat. Berikut temuan yang terdapat dalam PS.

(7) Manut Mahfud MD mantan Ketua $M K$, wong sing Golput kuwi bakal rugi dhewe. (PS 13/ 25-3-19)

'Menurut Mahfud MD, mantan Ketua MK, orang yang Golput itu akan rugi sendiri'.

(8) Kabar becik paling anyar dikabarake Jaksa Agung $H$ M Prasetya lan Menkeu Sri Mulyani Indrawati. (PS18/4-5-19)

'kabar baik terbaru dikabarkan Jaksa Agung H M Prasetya dan Menkeu Sri Mulyani Indrawati'.

(9) Ing kampanye akbar dina minggu (7 April Kepungkur) iki ing Stadion Utama Gelora Bung Karno Senayan. (PS17/27-4-19) 'di kampanye akbar hari minggu (7 April yang lalu) di Stadion Utama Gelora Bung Karno Senayan'.

(10) Dokumen kepemiluan liyane kaya C1 disalin saka C1 plano (PS19/11-5-19)

'Dokumen pemilu lainya seperti C1 disalin dari C1 plano'.

Data (7)--(10) di atas memiliki ciri aposisi yang khas, yaitu konstituen satu dan yang lain tak dipisahkan dengan tanda koma. Hal tersebut menandai bahwa data di atas dapat disebut aposisi mewatasi. Ciri lain aposisi jenis ini adalah salah satu kontituen, yaitu frasa nomina merupakan suatu gelar, jenis, pangkat atau jabatan dan konstituen lainya adalah nama diri atau nama benda.

Data (7) dan (8) menunjukan fenomena yang sama. Data tersebut termasuk data aposisi mewatasi. Data (7) menjelaskan Jabatan dari orang bernama Mahfud MD. Data (8) menanadai pewatasan nama orang yang menduduki jabatan Jaksa agung dan Menkeu.

Berbeda dengan data sebelumya, data (9) mewatasi waktu dilaksanakan kegiatan serta menginformasikan secara akurat kapan kejadian tersebut terjadi. Terakhir data (10), data tersebut mewatasi jenis dokumen. Hal tersebut merujuk pada banyaknya jenis dokumen dalam pemilu 2019. 


\subsection{Motif Aposisi}

Motif aposisi yang ditemukan dalam penelitian ini, antara lain ketercukupan informasi, penjelas istilah, pemberi informasi baru, kompetisi bahasa, pembentuk citra, penekanan emosi, penghormatan dan pembangun humanism. Berikut pemaparannya.

\section{a) Ketercukupan Informasi}

Aposisi memiliki fungsi sebagai penjelas suatu informasi untuk menambah wawasan pengetahuan pembaca terhadap sesuatu hal yang baru atau hal yang asing. Dalam produksinya, aposisi dapat muncul lebih dari satu konstituen. Jika aposisi dianggap kurang mencukupi, maka penulis akan menambahkan konstituen secukupnya guna keterpaduan informasi. Berikut temuan dalam majalah PS.

(11) Mangka Capres alternatif mau sedinane mung tukang pijet refleksi saka Desa Golantepus Kec. Mejobo, sing bukak kios ing Pasar Brayung, Kudus (Jateng). (PS 13/ 25-3-19) 'Padahal Capres alternatifnya itu hanya tukang refleksi dari Desa Golontepus Kec. Mejobo yang membuka kios di Pasar Brayung, Kudus (Jateng)'.

(12) Wis kakehan banget pejabat negara saka sakabehing tingkat kekuwasan, legislatif, eksekutif, lan yudikatif sing ngringkel ing pakunjaran merga tumindak korupsi. (PS17/ $27-$ 4-19)

'Sudah banya sekali pejabat dari semua tingkat kekuasaan, leglislatif, eksekutif, dan yudikatif yang mendekam di penjara karena tindakan korupsi'.
(13) Integrase, kaya ngendikane Presiden Jokowi mawarna program transportasi kaya MRT, LRT (light Rail Train) Bus trans Jakarta, KRL (kereta rel listrik), lan angkutan liyane. (PS15/13-4-19)

'Integrasi, seperti yang dikatakan Presiden Jokowi bermacam program transportasi seperti MRT, LRT (light Rail Train) Bus trans Jakarta, KRL (kereta rel listrik), dan angkutan lainya'.

Data (11) memberikan gambaran yang jelas terhadap informasi yang akan disampaikan oleh penulis. Hal tersebut sangat membantu pembaca untuk memahami informasi dengan sangat detail. Aposisi yang digunakan dalam penjelasan di atas adalah aposisi tidak penuh atau sebagian.

Aposisi di atas merupakan wujud dari pelengkap kategori keterangan. Dapat dicermati maujud dari aposisi di atas sangatlah unik, karena tidak digunakannya aposisi yang linier dalam penjelasan. Aposisi menggambarkan lokasi dan disisipi keterangan pekerjaan dari subjek yang menjadi pembahasan.

Data (12) merupakan motif aposisi ketercukupan informasi, menjelaskan secara rinci tentang siapa saja pejabat negara pemegang kekuasaan, yaitu legislatif, eksekutif, dan yudikatif. Selanjutnya data (13) merupakan aposisi penjelasan lebih lanjut dari akronim 
angkutan masal yang telah tersedia di Jakarta.

\section{b) Penjelas Istilah}

Dalam perkembangan zaman dan diikuti oleh perkembangan arus teknologi serta adanya pergolakan politik tidak dipungkiri akan diproduksinya istilahistilah yang asing dan tidak dimengerti oleh pembaca. Untuk itu aposisi digunakan untuk memeberikan kejelasan terhadap istilah asing tersebut, sehingga pembaca tidak bingung terhadap hal tersebut. Berikut data yang ditemukan.

(14) Nggatekake lan ngajeni (peka) marang sakupenge? (PS16/ 20-4-19) 'Memperhatikan dan menghargai (peka) marang sekitarnya?'.

(15) Yen debat kapisan ana Cawapres sing "anteng jinem" (kurang gunem), debat kapindho iki Jokowi-Prabowo bisa uncal-uncalan pitakon lan adu kasudibyan kanggo ngirup suwara, pindhane Adipati Karno-Harjuna jroning pabaratan Baratayuda. (PS924-2-19)

'Kalau debat pertama ada Cawapres yang 'tak berkata apa-apa' (kurang aktif) debat kedua Jokowi-Prabowo bisa saling melemparkan pertanyaan dan beradu program baik untuk menghimpun suara rakyat, seperti Adipati Karno-Harjuna dalam peperangan Baratayudha'.

Data (14) dan (15) menunjukkan aposisi sebagai wujud penjelas suatu istilah. Dalam hal ini kontituen penjelas diwujudkan dengan penanda kurung (). Melalui aposisi penjelas istilah, penulis berita ingin mempermudah pembaca dalam memahami maksud tulisan dengan penggunaan pilihan bahasa sebagai sinonimi yang lebih mudah dipahami dan lebih sering digunakan dalam tindakan berbahasa sehari-hari.

\section{c) Pemberian Informasi Baru}

PS sebagai media cetak memiliki peran sangat besar dalam peyampaian informasi baru yang bertanggung jawab. Menurut Ardhian (2013: 58), dalam rangka mendidik pembaca, informasiinformasi baru dan relevan penting untuk disuguhkan. Aposisi memiliki peran penting dalam mewujudkan hal tersebut.

(16) Ing jagad maya ana CapresCawapres alternatip aran NurhadiAldo, sing munggah blabar kawat tanpa nggunakake parpol kanggo kendaraan politik. (PS13/25-3-19) 'Di dunia maya ada CapresCawapres alternatif bernama Nurhadi-Aldo, yang mencalonkan tanpa menggunakan parpol untuk kendaraan politik.'

(17) Audrey, nom noman sing nandhang tatu jalaran kapilara sacara kroyokan, saiki lagi rame kabirawakake ing jagad medhia sosial. (PS16/ 20-4-19)

'Audrey, pemuda yang kesakitan karena dikeroyok, sekarang sedang ramai diperbincangkan di dunia media sosial'.

(18) Kabar becik paling anyar dikabarake Jaksa Agung $H \quad M$ Prasetya lan MenKeu Sri Mulyani Indrawati. (PS18/4-5-19)

'Kabar baik terbaru dikabarkan Jaksa Agung H M Prasetya dan Menkeu Sri Mulyani Indrawati'. 
Data (16) merupakan jenis aposisi penuh mewatasi subjek. Dari aposisi tersebut dapat diperoleh informasi baru berkenaan dengan adanya caprescawapres tandingan di dunia maya, yaitu bernama Nurhadi-Aldo. Aposisi pada data (16) merupakan aposisi penuh mewatasi, kontituen satu dan yang lain dapat saling mengganti tanpa merusak kegramatikalan kontruksi kalimat.

Data (17) nom noman sing nandhang tatu jalaran kapilara sacara kroyokan 'pemuda yang kesakitan' karena dikeroyok' merupakan informasi baru yang melekat pada pronominal “Audrey". Jika konstituen aposisi pewatas tersebut dihilangkan maka pembaca akan mengalami kekaburan makna ketika membaca berita tersebut.

Selanjutnya, data (18) menjelaskan nama pemegang jabatan. Jika informasi nama tersebut dihilangkan, maka pembaca tidak tahu siapa yang dimaksud. Konstituen aposisi pada data (18) adalah nama atau penanggung jawab instansi. Jenis aposisi adalah aposisi penuh mewatasi.

\section{d) Kompetisi bahasa}

Majalah PS merupakan majalah yang teguh pendiriannya untuk menggunakan bahasa Jawa dalam redaksinya. Namun, tak dapat dihindari bahwa seiring perkembangan zaman, para jurnalis juga menggunakan gaya bahasa yang berbeda, seperti bahasa asing, slang, ataupun register.

(19) Kanthi sesanti "Menuju Indonesia Tronjal Tronjol Maha Asyik", senajan sipate mung dhagelan Basiyonan, sutresnane (follower) ngedab-edabi. (PS13/25-3-19)

'Dengan semboyan "Menuju Indonesia Tronjal Tronjol Maha Asyik", meskipun sifatnya hanya sekedar guyonan, pengikut (follower)-nya banyak sekali'

(20) Para pendiri bangsa (Founding Fathers) sebenere wis ndelehake prinsip dhasar serta nuduhake kepriye SDA mau kudune diolah. (PS9/9-2-19)

'Para pendiri bangsa (founding fathers) sejatinya sudah meletakan prinsip dasar serta memberi tahu bagaimana SDA seharusnya diolah'.

Data (19) dan (20) memiliki konstituen satuan lingual yang sama dan merupakan perpadanan dan merupakan aposisi penuh yang dapat saling menggantikan. Munculnya bentuk padanan (sinonim) dari bahasa yang berbeda akan menimbulkan kompetisi bahasa.

Pemunculan kompetisi pada data (19) dan (20) memiliki motif yang berbeda. Data (19) menjelaskan penulis ingin memberikan pandangan bahwa bahasa Jawa harus diutamakan dalam majalah ini. Penulis memaksa mengadaptasi istilah followers 
dipadankan secara langsung dengan kata sutresnan atau 'pecinta'.

Data (20) merupakan penggunaan aposisi menilik pada keakraban istilah. Istilah founding father lebih terkenal. Namun, karena penulis berita ingin memberikan penghargaan pada bahasa Indonesia dan bahasa Jawa, penggunaan istilah asing selalu dituliskan setelah istilah Jawa atau Indonesia.

e) Pembentuk Citra Tokoh, Instansi, atau Kelembagaan

Pembentukan citra merupakan praktik jurnalistik yang tidak dapat dihilangkan untuk menggiring opini. Citra yang dapat dibangun dari praktik jurnalistik adalah citra baik dan buruk. Pemilihan diksi dalam konstituen aposisi berperan penting dalam pembangunan citra tersebut.

(21) Jakarta, Ibukota minangka pusat pemerintahan sarta pusat perekonomian saya kabotan mikul masalah saktumpuk. (PS15/13-4-19) 'Jakarta, Ibukota yang menjadi pusat pemerintahan sarta pusat perekonomian semakin keberatan memikul setumpuk masalah'.

(22) Prestasi uga mbuktekake yen bangsa kita kuwawa banget (kelas wahid) jroning ngadepi kasus hukum kalebu tingkat internasional. (PS17/27-419)

'Prestasi juga membuktikan jika bangsa kita sangat baik (kelas wahid) dalam menghadapi kasus hukum tingkat internasional'.
Data (21)--(22) menandakan bahwa kehadiran aposisi turut membangun citra dan juga berpengaruh dalam pembentukan opini. Dalam hal ini bertepatan semua data mengarah pada suatu tempat (kota dan negara). Data (21) merupakan data aposisi yang konstituen penjelasnya menjelaskan tentang citra sebuah kota yang bernama Jakarta. Citra yang dibentuk dari konstituennya adalah menguatkan citra dari kota Jakarta sebagai ibu kota Negara Republik Indonesia adalah kota yang sangat sibuk, padat, dan penuh dengan aktivitas perkantoran, dll serta berimplikasi pada masalah yang sulit terurai.

Data (22) memberikan citra baik terhadap pemerintahan Indonesia dengan pemilihan diksi "kelas wahid". aposisi bersinonimi tersebut menggunakan daya hiperbola dalam menggiring asumsi yang sangat baik kepada pembaca terhadap kinerja yang sangat baik pemerintah pada bidang hukum.

\section{f) Penekanan Emosi}

Aposisi secara umum memiliki fungsi sebagai pelengkap informasi. Namun, dalam PS telah ditemukan data aposisi memilki kecondongan maksud sebagi wahana ekspresif penulis. Berikut wujud penekanan emosi yang ada dalam konstituen aposisi. 
(23) Jenenge pesta lumrahe swasanane rame nyenengake, gumbira, padha suka parisuka. (PS13/23-3-19)

'Namanya pesta umumnya suasananya ramai menyenangkan, menggembirakan, sama-sama suka'.

Aposisi pada data (23) memiliki konstituen lingual yang bersinonimi satu sama lain. Penekanan pada konstituen aposisi tersebut ditekankan pada kelas kata adjektiva nyenengake, gumbira, suka pari suka memiliki makna 'bergembira dan suka sama suka'. Penekanan dengan kemunculan 3 konstituen aposisi tersebut menggiring opini bahwa masyarakat harus bergembira dengan datangnya pemilu karena pemilu adalah pesta demokrasi.

\section{g) Penghormatan}

Motif aposisi lain yang ditemukan dalam majalah PS, adalah penghormatan. Dalam hal ini aposisi memiliki peran khusus dalam menggiring opini terhadap sesuatu. Berikut temuan data dari majalah PS.

(24) ingkang minulya sesostyaning Senayan saha dhahat kinurmatan bapa Fadli Zon, datane Jokowi akeh ngawure. (PS9-24-2-19)

'Yang terhormat perwakilan Senayan serta paling terhormat bapa Fadli Zon, datanya Jokowi banyak yang ngawur'.

Data (24) konstituen pertama aposisi menjelaskan tentang posisi Fadli Zon yang merupakan petinggi dari DPR. Penulis menggunakan gaya bahasa yang unik dengan penggunaan bahasa ragam panggung. Hal tersebut dijelaskan dengan penggunaan infiks -in-, serta pilihan asonansi la/ yeng merujuk pada keagungan.

\section{h) Pembangun Humanisme}

Praktik jurnalisme juga berperan dalam menampilkan sisi-sisi humanis suatu gaya pemberitaan. Praktik humanisme tersebut digambarkan pada contoh aposisi berikut.

(25) Minangka warga negara lumrah (wong cilik), saben dina kita tansah ibut ngemonah ekonomi. (PS6/2-2-19)

'Sebagai warga negara (wong cilik), setiap hari kita sibuk untuk mencukupi ekonomi'

Data (25) konstituen aposisi menggunakan pilihan diksi yang mengandung majas peyorasi. Hal tersebut memberikan citra lemah dan tak berdaya tak punya kuasa pada pilihan kata wong cilik.

\section{Penutup}

Jenis aposisi bahasa Jawa yang digunakan dalam PS adalah tiga jenis, yaitu aposisi penuh, aposisi sebagian (tak mewatasi), dan aposisi mewatasi. Sementara itu, ada delapan motif tujuan aposisi dalam PS, yaitu ketercukupan informasi, kejelasan istilah, pemberian informasi baru, kompetisi bahasa, 
pembentukan citra tokoh, instansi, dan lembaga, penekanan emosi, pembangunan emosi, penghormatan, dan pembangun segi humanisme. Dari penjabaran temuan di atas terdapat motif baru yang ditemukan peneliti dalam penggunaan aposisi, yaitu penekanan emosi dan penghormatan. Penggunaan motif aposisi tersebut memberikan kesan lebih komunikatif dan informatif dari majalah PS. Selanjutnya, penggunaan aposisi yang relatif memiliki frekuensi yang tinggi dalam PS menunjukan bahwa pada rubrik Pangudarasa ingin memberikan informasi secara rinci dan jelas terhadap fenomena yang sedang terjadi.
Curme, G. (1947). English Grammar. New York: Barnes and Noble.

Favre, Benoit dan Dilek Hakkani-Tür. (2009). Phrase and Word Level Strategies for Detecting Apposition in Speech. Dalam Interspeech 2009 Brighton. Berkeley: ICSASSP Hal 2711-2714.

Paladian, M. (2003). Apposition. Investigationes Linguisticae, vol. $X$, Poznan.

Sudaryanto. (2015). Metode dan Aneka Teknik Bahasa: Pengantar Penelitian Wahana Kebudayaan secara Linguistis. Yogyakarta: Sanata Dharma University Press.

Sugono, Dendy. (2002). Berbahasa Indonesia dengan Benar. Jakarta: Puspa Swara.

Verhaar, J.W.M.2010. Asas-Asas Linguistik Umum (cetakan ketujuh).Yogyakarta: Gadjah Mada University Press.

\section{Daftar Pustaka}

Alisjabana, S.T. 1953. Tata Bahasa Baru Bahasa Indonesia (Jilid Kedua). Jakarta: Pustaka Rakyat.

Alwi, Hasan, dkk. (2010). Tata Bahasa Baku Bahasa Indonesia (edisi ketiga cetakan kedelapan). Jakarta: Balai Pustaka.

Ardhian, Dany. (2013). Aposisi Bahasa Indonesia. Dalam TransLing Journal: Translation and Linguistics Vol 1, No 1.

Cahyana, Dian Anik. (2017). Aposisi Pada Teks Berita Utama Jawa Pos. Dalam LiNGUA Vol 12, No 1. 
Jenis dan Motif Konstruksi ... (Titis Bayu W. dan Sumarlam)

110 | Mabasan, Vol. 13, No. 2, Desember 2019, hlm. 97-110 p-ISSN: 2085-9554, e-ISSN: 2621-2005 